\title{
Severe Hyponatremia and Water Intoxication - Diagnostic Challenge in Department of Emergency Medicine
}

\author{
Jure Pupić-Bakrač ${ }^{1}$, Jeremije Radović ${ }^{1}$, Ana Pupić-Bakrač ${ }^{2}$, \\ Dino Markota ${ }^{3}$, Dušan Pupić-Bakrač ${ }^{4}$ \\ ${ }^{1}$ Department of Emergency Medicine, University Clinical Hospital Mostar, Bosnia and \\ Herzegovina, ${ }^{2}$ Department of Ophthalmology, General hospital Zadar, Croatia, ${ }^{3}$ Depart- \\ ment of Internal Medicine, University Clinical Hospital Mostar, Bosnia and Herzegovina, \\ ${ }^{4}$ Sanus Medical Group, Zadar, Croatia
}

\begin{abstract}
Psychogenic polydipsia is a disorder characterized by compulsive drinking of water in a population of psychiatric patients, most often those suffering from chronic psychosis. It can lead to severe dilutional hyponatremia and water intoxication, which is manifested by cerebral edema and associated neurological symptomatology. A 43 years-old patient was admitted to the Department of Emergency Medicine due to convulsions of the right hand and leg, which began one hour before arrival. During the episode, the patient was conscious, vomited once and had urinary incontinence. In the medical history he had epilepsy, chronic psychosis and moderate mental retardation. Vital parameters were stable, and physical examination did not reveal any associated pathological signs. Samples for laboratory analysis were taken and therapy with infusions of Diasepam $(20 \mathrm{mg}$ ) included, to which patient was resistant. By heteroanamnesis it was acknowledged that in the last few days he spent more time than usual drinking water. Reviewing laboratory results it was found out that sodium concentration was $98 \mathrm{mmol} / \mathrm{L}$. We began the gradual correction of sodium, after which the patient reached the full extent of recovery. Water intoxication is an emergency condition that is in clinical practice often mistaken for other neurological and internal emergency states, because of its non-specific symptomatology. With timely diagnosis and application of adequate treatment, recovery is complete.
\end{abstract}

Keywords: polydipsia, psychogenic; hyponatremia; water intoxication

Copyright @ 2017 KBCSM, Zagreb

e-mail: alcoholism.kbcsm@gmail.com • www.http//hrcak.srce.hr/acoholism

Correspondence to: Jure Pupić-Bakrač, Department of

Emergency Medicine, University

Clinical Hospital Mostar, Bijeli Brijeg bb, 88000 Mostar, Bosnia

and Herzegovina

Telephone: +385989764788

E-mail: jureppbkr2@gmail.com

\section{Introduction}

Hyponatremia is the most common electrolyte imbalance, and is defined as the sodium concentration below $135 \mathrm{mmol} / \mathrm{L}$. It is classified as mild $(130-134 \mathrm{mmol} / \mathrm{L})$, moderate (125-129 mmol / L), severe (120$124 \mathrm{mmol} / \mathrm{L})$ and extremely severe $(<120$ mmol / L) [1]. Etiologically, many factors 
may be the cause of hyponatremia, and some of the most common are heart, kidney and liver diseases, inappropriate antidiuretic hormone syndrome, certain drugs, vomiting and diarrhea, increased water intake, dehydration, consumption of ecstasy, etc. [2].

Increased water intake (polydipsia) is a factor that can cause severe dilutional hyponatremia and consequently water intoxication. Water intoxication is a life-threatening condition due to the decrease of serum osmolality and the diffusion of water into the intracellular space, which is primarily manifested by brain edema. Symptomatology depends on serum sodium levels and the speed of hyponatremia development. It includes the following symptoms and signs: nausea, vomiting, headache, confusion, fatigue, agitation, hypotonia, convulsions, coma and ultimately death. The neurological deficit in most cases progresses proportionally to the severity of sodium deficit. Lethal outcome is the consequence of increased intracranial pressure and herniation of cerebellar tonsils below foramen magnum [3].

Polydipsia is a condition that can be caused by various factors, for example endurance sports, overhydration in heat, attempt to conceal doping abuse, water abuse, water diet, drug induced polydipsia etc. [4]. A special subset of polydipsia is psychogenic polydipsia, characterized by compulsive drinking of water in a population of psychiatric patients, most often those suffering from psychosis [5]. At the Department of Emergency Medicine, water intoxication can be a major diagnostic challenge, especially in the sense of differential diagnosis versus neurological conditions such as epilepsy. Psychiatric diagnoses are often associated with other conditions and factors (the existence of prior neuropsychiatric and internal symptoms, psychopharmacs, alcoholism, mental retardation, poor anamnesis) that can initially mislead the clinician. Early detection and treatment of water intoxication can save life.

\section{Case presentation}

A 43-year-old patient was admitted to the Department of Emergency Medicine for a convulsive episode. According to the report of the nurse accompanying the patient, one hour prior to arrival he continuously began to spasm his right hand, leg and right side of the face. He was conscious and verbally communicative the whole time during the episode. He vomited once and had urinary incontinence. He did not suffer head trauma nor was febrile in the past period.

From the medical history, it was learned that the patient was suffering from chronic psychosis and moderate mental retardation, for which he was permanently situated in the facility for adults with special needs. Also, he had recorded epileptic seizures and was on antiepileptic therapy. He has been treated for hypertension, and in the last 6 months for recurrence of tuberculosis. The therapy con-

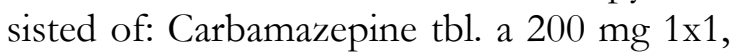
Sodium valproate tbl. a $300 \mathrm{mg} 2 \times 2$, Haloperidol tbl. a $5 \mathrm{mg} 1+1+2$, Promazine tbl. a $100 \mathrm{mg} 1+1+1.5$, Diasepam tbl. a $5 \mathrm{mg}$ $3 \times 1$, Biperiden hydrochloride tbl. a $2 \mathrm{mg} 1 \mathrm{x} 1$, Lisinopril tbl. a $10 \mathrm{mg} 1 \mathrm{x} 1$, Amoxicillin caps. a $500 \mathrm{mg} \mathrm{3 \times 1}$, and antituberculous therapy according to the protocol for recurrence (Streptomycin amp. a $750 \mathrm{mg} \mathrm{1x1} \mathrm{i.m} \mathrm{-} \mathrm{for}$ first two months, Isoniazid tbl. a $75 \mathrm{mg} 1 \mathrm{x} 4+$ Rifampicin tbl. a 150 mg 1x4 + Pyrazinamide tbl. a $400 \mathrm{mg} 1 \times 4$ + Ethambutol tbl. a $275 \mathrm{mg}$ $1 \times 4$ - for first three months; Isoniazid tbl. a $75 \mathrm{mg} 1 \mathrm{x} 4$ + Rifampicin tbl. a $150 \mathrm{mg} 1 \times 4+$ Ethambutol tbl. a $275 \mathrm{mg} 1 \mathrm{x} 4$ and $\mathrm{B}$ complex tbl. $3 \times 1$ - for next five months). 
Table 1. Concentration of sodium, potassium, chloride, urea and creatinine during 8 days of hospitalization, and on control examination (23 days after admission); $\mathrm{Na}+-$ sodium, $\mathrm{K}+-$ - potassium, $\mathrm{Cl}-$ - chloride.

\begin{tabular}{llllllllll}
\hline Parameter & Day 1 & Day 2 & Day 3 & Day 4 & Day 5 & Day 6 & Day 7 & Day 8 & Day 23 \\
\hline $\mathrm{Na}^{+}(\mathrm{mmol} / \mathrm{L})$ & 98 & 106 & 108 & 114 & 128 & 128 & 129 & 128 & 144 \\
$\mathrm{~K}^{+}(\mathrm{mmol} / \mathrm{L})$ & 3.2 & 3.9 & 4.3 & 4.1 & 3.5 & 3.8 & 4.0 & 4.1 & 5.3 \\
$\mathrm{Cl}^{-}(\mathrm{mmol} / \mathrm{L})$ & 64 & 72 & 73 & 79 & 96 & 94 & 91 & 94 & 103 \\
Urea $(\mathrm{mmol} / \mathrm{L})$ & 1.4 & 2.8 & 1.9 & 1.0 & 1.9 & $/$ & 4.1 & 2.5 & $/$ \\
Creatinine $(\mu \mathrm{mol} / \mathrm{L})$ & 49 & 58 & 53 & 48 & 47 & $/$ & 74 & 54 & $/$ \\
\hline
\end{tabular}

The following physical status was described after the clinical examination: the patient had an asthenic physique, he was conscious, disorientated in space and time, verbally contactable, and with deficient thought content, in a mild psychomotor disorder, eupneic in rest. The eyes were normally positioned, pupils isochoric, with normal reactions to light. The physical examination of the head and cranial nerves was without a pathological substrate. Meningeal signs were negative. In the upper and lower Mingazzini test there were no signs of lateralization. In the standing position, patient was falling forward. Deep tendon reflexes were of appropriate and symmetric response. Pathological reflexes were not present. The patient was in diapers, with urinary incontinence.

There were no pathological signs on the electrocardiogram and the vital parameters were as follows: RR 165/100 mm Hg, heart rate 72 / min, hemoglobin oxygen saturation (SpO2) 98\%, blood sugar level (BSL) 7.2 $\mathrm{mmol} / \mathrm{L}$, axillary temperature (Tax) $36.7^{\circ} \mathrm{C}$.

After the examination, samples were taken for laboratory analysis of blood (CBC and standard biochemistry), urine and arterial blood gases (ABG). The following therapy was ordered: Diasepam sol. a $10 \mathrm{mg}+$
$0.9 \% \mathrm{NaCl}$ sol. a $250 \mathrm{~mL}$ x 2; to which patient was unresponsive in clinical status. An emergency brain Multislice Computed Tomography scans showed atrophy of cerebral parenchyma, and no acute pathomorphological changes.

We got information from facility staff by phone that patient spent a lot of time near the water tap in the past few days (probably drinking large amounts of water). Due to suspicion of possible hyponatremia, infusion of $0.9 \% \mathrm{NaCl}$ sol. a $500 \mathrm{~mL}$ was included in the therapy while waiting for laboratory findings. Reviewing the laboratory results of standard biochemistry, it was observed that sodium concentration was $98 \mathrm{mmol} / \mathrm{L}$. The urine and $A B G$ results were within the reference values (urine specific gravity: $1010 \mathrm{~kg} / \mathrm{L}$ ).

The patient was hospitalized to a Polyvalent Intensive Care Unit and the correction of sodium concentration started by restriction of water intake (maximum $2 \mathrm{~L} / \mathrm{day}$ ), infusions of hypertonic $\mathrm{NaCl}$ solution (7.5\%) and preoral salt intake. During the 8 days, gradual titration of the mineral concentration (Table 1) was achieved and the initial diuresis of $15,000 \mathrm{~mL}$ was reduced to $3500 \mathrm{~mL}$ (urinary output measured by indwelling catheter). During hospitalization, the patient was 
with normal vital parameters, hemodynamically stable, without repeated convulsive seizures. Consequently, he was examined by the psychiatrist, who made the modification of neuropsychiatric therapy. Internist therapy was also adapted. Therapy at discharge was: Amlodipine tbl. a $10 \mathrm{mg}$ 1x1, Metoprolol tbl. a $12.5 \mathrm{mg} 2 \times 1$, Sodium valproate tbl. a 300 mg $1+0+2$, Haloperidol tbl. a 2 mg 3x1, Promazine tbl. a $25 \mathrm{mg} 1+1+2$, Diasepam tbl. a $5 \mathrm{mg} 3 \times 1$, Biperiden hydrochloride tbl. a $2 \mathrm{mg} \mathrm{1x} 1$ and extension of antituberculous therapy. The ninth day after admission, the patient was released to the facility for adults with special needs. The medical staff were given instructions on the control of peroral water intake and the need for periodic tests of serum electrolytes.

\section{Discussion}

The pathophysiology of psychogenic polydipsia is still not completely understood. The current researches suggest that it is a result of combined impact of several factors. The generally accepted explanation is that patients with psychogenic polydipsia have impairment of thirst center function, thus they have a much lower threshold for thirst than the general population. This results in polydipsia until the plasma osmolarity drops deeply below the physiological lev$\mathrm{el}$, even when antidiuretic hormone $(\mathrm{ADH})$ is fully suppressed. The probable cause for this malfunction is the disturbed interaction of neurotransmitters and hormones at the lymphic-hypothalamic-pituitary-adrenal axis level. Apart from psychotic decompensation, factors for exacerbation may be certain psychopharmaceuticals, decreased levels of potassium and others [6]. Among patients, the most common answer to the question why they drink, was not because of the feel of thirst but because they wanted to clean, wash or rinse worms for example, therefore patients usually gave delusional explanations [7]. Epidemiologic researches by authors from the US showed that $5 \%$ of chronic psychiatric patients had at least once in a lifetime an episode of water intoxication. About $20 \%$ of all respondents had psychogenic polydipsia, of which about $30 \%$ progressed to water intoxication. About $80 \%$ of respondents who had diagnosis of psychogenic polydipsia were from the "schizophrenic" group $[8,9]$.

At the Department of Emergency Medicine, the major clinical challenge is to recognize water intoxication from other emergency conditions and promptly administer adequate treatment. In extremely severe acute hyponatremia the clinical picture rapidly progresses to coma and death outcome $[3,10]$. In presented case, the patient was particularly complicated because of a diagnosis of idiopathic epilepsy in medical history, with antiepileptic therapy prescribed. Given the clinical picture dominated by the seizures of the right extremities, nausea and urinary incontinence, a primary diagnosis of partial epileptic seizures was established. Since the patient was resistant to the ordered therapy, we had doubts about the possible secondary cause of seizures. Detailed heteroanamnesis and insight into the laboratory results gave us a final answer on presence of dilution hyponatremia and water intoxication.

This case is also interesting because of another fact, and that is an extremely low sodium level of $98 \mathrm{mmol} / \mathrm{L}$ which is, according to our findings, one of the lowest measured concentrations in the serum of the living man. Previously, only few cases with a sodium concentration of less than $100 \mathrm{mmol}$ / $\mathrm{L}$ were reported in the literature $[11,12,13]$. 
However, in most cases hyponatremia was caused by a different mechanism, within the syndrome of inappropriate antidiuretic hormone secretion (SIADH) [12,13]. Among the general population, the fatal outcome occurs at considerably higher sodium concentrations, usually below $120 \mathrm{mmol} / \mathrm{L}^{10}$. Possible cause for tolerance of such an extreme hyponatremia in our case is chronic water intoxication, i.e. development of intoxication over a period of more than 48 hours. Brain adaptation to reduced serum osmolarity begins immediately after initial sodium level decline and ends after 2-3 days [14]. It happens in a way that brain cells lose soluble substances with the consequent osmotic movement of water from the cells, thereby reducing brain edema. Due to brain's acclimatization to new homeostasis, symptomatology of chronic intoxication is much more subtle than that of an acute intoxication (development within 48 hours) [15]. This is also evident from the example of our patient, whose clinical picture, given the severity of hyponatremia, was much milder than expected. It is a trap that, in practice, can lead the clinician to underestimate the condition of the patient and postpone the correct diagnosis and application of treatment.

Furthermore, chronic water intoxication has its own specificity vis-à-vis acute in therapeutic terms. The recoupment of sodium in the chronic form should be gradual and carefully titrated, as rapid plasma osmolality increase causes brain cell drainage and consequent demyelination. Osmotic demyelination can lead to irreversible neurological deficits, seizures, coma, and in severe cases - death [16]. Therefore, not only that the diagnosis of water intoxication should be differentiated from other medical conditions, but it should also be differentiated whether it is acute or chronic intoxication. If based on anamnesis and clinical examination we cannot safely determine the time of development of water intoxication, it is best to assume that it is a chronic condition and treat it that way [12].

Except psychogenic polydipsia, other possible factors associated with pathophysiology of hyponatremia in the presented case could be the consumption of certain medications and hypokalemia. Our patient had Carbamazepine in his therapy, and it is proven that this antiepileptic is associated with drug-induced hyponatremia [17]. He was also treated with several other medications that were reported to have an effect on lowering serum sodium within SIADH - Sodium valproate [18], Haloperidol [19] and Lisinopril [20]. Furthermore, antipsychotics he consumed have dry mouth as a side effect, and consequent excessive water intake [6]. Mild hypokalemia, acknowledged from laboratory findings, could arise as a result of malnutrition (as the patient was asthenic and with recurrence of tuberculosis), but also due to vomiting. Conclusively, the pathophysiology of hyponatremia was most likely multifactorial, with the combined influence of all listed factors.

\section{Conclusion}

Water intoxication is an emergency medical condition that is, due to non-specific symptomatology and low incidence, initially often replaced with neurological and internal emergency conditions, especially if they are present in the medical history. In patients with a psychiatric diagnosis (schizophrenia, anorexia nervosa, personality disorders, autism, anxiety-depressive disorder, etc.), especially those suffering from chronic psychosis, that are developing acute neurological symptomatology, it is always necessary to differen- 
tial-diagnostically think about possibility of water intoxication. Water intoxication, even with extremely severe hyponatremia, can be treated to the full extent of recovery, without residual neurological deficits.

\section{References}

1. Prkacin I, Coric Martinovic V, Dermanovic Dobrota V, Legović A, Vrhovec B, Cavrić Gordana et al. Incidence of hyponatraemia in the emergency unit. Signa Vitae. 2015;10:29-31.

2. SahayM, Sahay R. Hyponatremia: A practical approach. Indian J Endocrinol Metab. 2014;18:76071.

3. Farrell DJ, Bower L. Fatal water intoxication. J Clin Pathol. 2003;56:803-4.

4. Radojevic N, Bjelogrlic B, Aleksic V, Rancic N, Samardzic M, Petkovic S et al. Forensic aspects of water intoxication: four case reports and review of relevant literature. Forensic Sci Int. 2012;220:1-5.

5. Dundas B, Harris M, Narasimhan M. Psychogenic polydipsia review: etiology, differential, and treatment. Curr Psychiatry Rep. 2007;9:236-41.

6. Aukst-Margetić B, Margetić B. Polidipsija i hiponatrijemija u bolesnika s shizofrenijom. Soc Psihijat. 2000;28:131-7.

7. Illowsky BP, Kirch DG. Polydipsia and hyponatremia in psychiatric patients. Am J Psychiatry. 1988;145:675-83.

8. de Leon J, Dadvand M, Canuso C, Odom-White A, Stanilla J, Simpson GM. Polydipsia and Water Intoxication in a Long-Term Psychiatric Hospital. Biol Psychiatry. 1996;40:28-34.

9. de Leon J, Verghese C, Tracy JI, Josiassen RC, Simpson GM. Polydipsia and Water Intoxication in Psychiatric Patients: A Review of the Epidemiological Literature. Biol Psychiatry. 1994;35:40819.

10. Dundas B, Harris M, Narasimhan M. Psychogenic polydipsia review: etiology, differential, and treatment. Curr Psychiatry Rep. 2007;9:236-41.

\section{Acknowledgements}

None

\section{Conflict of interest}

None to declare

11. Lohr JW. Osmotic demyelination syndrome following correction of hyponatremia: association with hypokalemia. Am J Med. 1994;96:408-13.

12. Ijaiya $T$, Manohar S, Lakshmi K. Therapeutic Approach to the Management of Severe Asymptomatic Hyponatremia. Case Rep Nephrol. 2017;2017:1371804.

13. Franklin J, Kaliyaperumal M, Moss N, Qedwai F, Hill C, Khalleli AA. Severe hyponatremia - how low can you go? Endocrine Abstracts. 2007;13:p. 43.

14. Douglas I. Hyponatremia: why it matters, how it presents, how we can manage it. Cleve Clin J Med. 2006;73:4-12.

15. Sterns RH, Silver SM. Brain volume regulation in response to hypo-osmolality and its correction. Am J Med. 2006;119(Suppl.1):S12-16.

16. Saeed BO, Beaumont D, Handley GH, Weaver JU. Severe hyponatraemia: Investigation and management in a district general hospital. J Clin Pathol. 2002;55:893-6.

17. Berghuis B, an der Palen J, de Haan GJ Lindhout D, Koeleman BPC, Sander JW et al. Carbamazepine- and oxcarbazepine-induced hyponatremia in people with epilepsy. Epilepsia. 2017;58:1227-33.

18. Gupta E, Kunjal R, Cury JD. Severe Hyponatremia Due to Valproic Acid Toxicity. J Clin Med Res. 2015;7:717-9.

19. Michael T, Kenes MT, Hamblin SE, Tumuluri SS, Guillamondegui OD. Syndrome of Inappropriate Antidiuretic Hormone in a Patient Receiving High-Dose Haloperidol and Quetiapine Therapy. J Neuropsychiatry Clin Neurosci. 2016;28:29-30

20. Shaikh ZH, Taylor HC, Maroo PV, Llerena LA. Syndrome of inappropriate antidiuretic hormone secretion associated with lisinopril. Ann Pharmacother. 2000;34:176-9. 


\section{Ozbiljna hiponatrijemija i intoksikacija vodom- Dijagnostički izazov u hitnoj medicini}

Sažetak - Psihogena polidipsija je poremećaj kompulzivnog pijenja vodc u psihijatrijskih pacijenata, najčešće onih koji boluju od kronične psihoze. Poremećaj može uzrokovati tešku hiponatrijemiju i intoksikaciju vodom, a manifestira se putem cerebralnog edema i popratnih neuroloških simptoma. 43-godišnji pacijent zaprimljen je na odjel hitne medicine zbog konvulzija desne ruke i noge koje su započele jedan sat prije dolaska. Za vrijeme trajanja napada pacijent je bio pri svijesti, jednom je povraćao i imao urinarnu inkontinenciju. Anamneza je pokazala da pacijent boluje od epilepsije, kronične psihoze i umjerene mentalne retardacije. Vitalni parametri su bili stabilni i tijekom fizičkog pregleda nisu uočeni nikakvi popratni patološki znakovi. Uzeti su uzorci za laboratorijsku analizu i i putem infuzije je uključena terapija Diazepama (20mg) na koju je pacijent bio rezistentan. Iz heteroanamnestičkih podataka utvrđeno je da je pacijent posljednjih nekoliko dana proveo dosta vremena pijući vodu. Laboratorijski nalazi su pokazali da je koncentracija natrija $98 \mathrm{mmol} / \mathrm{l}$. Postepeno smo počeli normalizirati razinu natrija nakon čega se pacijent u potpunosti oporavio. Intoksikacija vodom je hitno stanje koje se u kliničkoj praksi često zamijeni s drugim neurološkim i internističkim hitnim stanjima zbog svoje nespecifične simptomatologije. Pravovremenom dijagnozom i odgovarajućom terapijom oporavak je potpun.

Ključne riječi: polidipsija, psihogen, hiponatrijemija, intoksikacija vodom 